\title{
ПИТАННЯ ЗАХИСТУ МЕДИЧНИХ ПРАЦІВНИКІВ У СТРАТЕГІЇ ПРОФЕСІЙНОГО МЕДСЕСТРИНСЬКОГО ТА МЕДИЧНОГО САМОВРЯДУВАННЯ В СИСТЕМІ ОХОРОНИ ЗДОРОВ'Я УКРАЇНИ
}

\section{Питання захисту медичних працівників у стратегії професійного медсестринського та медичного самоврядування в системі охорони здоров'я України}

\section{О. Н. Литвинова, А. Г. Шульгай, Г. С. Сатурська}

Тернопільський національний медичний університет імені І. Я. Горбачевського МОЗ України

Резюме. Заходи щодо ресрормування систем охорони здоров'я, які активно відбуваються останнім часом в Україні, а також зміни функціонування системи надання медичної допомоги в усьому світі у зв'язку з пандемію COVID-19, внесли значні корективи в роботу медичних працівників, особливо середнього медичного персоналу та лікарів, на яких припадає велике навантаження у роботі з пацієнтами первинного рівня надання медичної допомоги, а також цілодобового спостереження та догляду за хворими вторинного та третинного рівнів медичної допомоги. Для вирішення чієї проблеми ефективними є такі напрямки для покращення якості роботи медсестер і лікарів, як підтримка нових дипломованих медичних спеціалістів - лікарів і медсестер із різним рівнем освіти, створення для них можливостей для продовження освіти та набуття досвіду в певних галузях медицини та медсестринства, сприяння позитивним колегіальним відносинам, програми зниження стресу та збільшення фрінансової компенсації. В Україні цим питанням до сьогодні приділялося недостатньо уваги, що потребує пошуку шляхів їх розв'язання із залученням досвіду передових країн світу.

Мета дослідження - проаналізувати питання захисту інтересів медсестер та лікарів у системі охорони здоров'я України для можливостей вирішення цих проблем на засадах професійного самоврядування.

Матеріали і методи. Використовуючи методи системного аналізу, показано частку питань, що стосуються захисту інтересів медсестер та лікарів у самоврядних професійних організаціях в Україні.

Результати. Показано проблемні питання захисту інтересів медсестер та лікарів у закладах охорони здоров'я в Україні та шляхи їх вирішення через систему медичного самоврядування в ряді європейських країн. Розглянуто позитивні та проблемні сторони медичного самоврядування у питаннях відстоювання інтересів медсестер та лікарів. В Україні прообразом самоврядних організацій є громадські організації, такі,
Issues of medical workers' protection in the strategy of professional nursing and medical self-government in the healthcare system of Ukraine

O. N. Lytvynova, A. H. Shulhai, H. S. Saturska

I. Horbachevsky Ternopil National Medical University

e-mail: Iytvynova@tdmu.edu.ua

Summary. Recent health care reform measures in Ukraine, as well as changes in the functioning of the health care system throughout the COVID-19 pandemic, have made significant adjustments to the work of health professionals, especially medical nurses and physicians, who have a heavy workload at the primary level of healthcare, as well as round-the-clock monitoring and care at the secondary and tertiary level of healthcare. To address this problem, to improve the quality of work of nurses and doctors, the effective measures could be implemented, such as supporting new graduates - doctors and nurses with different levels of education, creating opportunities for them to continue their education and gain experience in certain fields of medicine and nursing, promoting positive collegial relations, creation of programs to reduce stress and increase financial compensation. In Ukraine, these issues have not received sufficient attention, therefore new ways to solve them are required taking into consideration of the experience of the developed countries.

The aim of the study - to analyze the issues of protection of the interests of nurses and doctors in the health care system of Ukraine for a possible solution to these problems based on the professional self-government.

Materials and Methods. Using the methods of system analysis, the share of issues related to the protection of the interests of nurses and doctors in self-governing professional organizations in Ukraine is shown.

Results. The problematic issues of protection of the interests of nurses and doctors in health care institutions in Ukraine and ways to solve them through the system of medical self-government in a number of European countries are shown. The positive and problematic aspects of medical self-government in defending the interests of nurses and doctors are considered. In Ukraine, the prototype of self-governing organizations are public organizations such as the Medical Society, the Association of Nurses and Doctors, etc. Unfortunately, the issue of the interests of nurses and doctors is rather weakly reflected 
як Лікарське товариство, Асоціації медсестер та лікарів тощо. На жаль, питання інтересів медсестер та лікарів у них відображено доволі слабко. Більше уваги вони приділяють можливостям участі у вирішенні державних питань охорони здоров'я, але лише з правом дорадчого голосу. Акцентовано на проблемних питаннях постійного навчання медсестер та лікарів. Саме органи медичного самоврядування можуть пропонуваmи та реалізовувати проекти та схеми підвищення кваліфікації, застосовуючи різноманітні мотиваційні чинники для удосконалення кваліфікації медперсоналу.

Висновки. Аналіз ситуації захисту медичних працівників та їх безпеки в системі охорони здоров'я України дозволив виявити певні проблеми, що здебільшого полягають у недостатніх правових та фрінансових гарантіях для медичних працівників, а також організаційних прогалинах, зокрема відсутності чіткої стратегії професійного медсестринського та медичного самоврядування. Причинами такої складної ситуації є нестача фінансування та управлінські проблеми. Щодо перспектив вирішення цього блоку питань, то найраціональніше вказані проблеми можуть бути вирішені органами медичного самоврядування при належному юридичному забезпеченні, чому сприятиме прийняття Закону про самоврядування медичних профресій в Україні.

Ключові слова: захист інтересів медсестри (медбрата) та лікаря; самоврядування; система охорони здоров'я; медична допомога.

\section{ВСТУП}

Заходи щодо редормуванню систем охорони здоров'я, які активно відбуваються останнім часом в Україні, а також зміни функціонування системи надання медичної допомоги в усьому світі [1] у зв'язку 3 пандемію COVID-19, внесли значні корективи в роботу медичних працівників, особливо середнього медичного персоналу та лікарів, на яких припадає велике навантаження у роботі з пацієнтами первинного рівня надання медичної допомоги, а також цілодобового спостереження та догляду за хворими вторинного та третинного рівнів медичної допомоги.

Відомо, що середовище або мікроклімат на робочому місці медичних працівників тісно пов'язаний із фрізичним і психологічним благополуччям, а також якістю життя медсестер і лікарів. Для вирішення цієї проблеми ефрективними є такі напрямки для покращення якості роботи медсестер і лікарів, як підтримка нових дипломованих медичних спеціалістів - лікарів і медсестер із різним рівнем освіти, створення для них можливостей для продовження освіти та набуття досвіду в певних галузях медицини та медсестринства, сприяння позитивним колегіальним відносинам, програми зниження стресу та збільшення фрінансової компенсації. В Україні цим питанням до сьогодні приділялося недостатньо уваги, що потребує пошуку шляхів їх розв'язання із залученням досвіду передових країн світу. in them. More attention should be paid to determine the opportunities for participation in the decision of public health authorities, but only with the right advisory vote. Emphasis is placed on the problematic issues of continuing education of nurses and doctors. It is the medical selfgovernment bodies that can propose and implement projects and schemes of professional development, using various motivating factors for professional development of medical staff.

Conclusions. Analysis of the situation of protection of health workers and their safety in the health care systems of Ukraine revealed certain problems, such as more insufficient legal and financial guarantees for health workers, as well as organizational gaps, with certain strategies of professional nursing and medical self-government. The reasons for this difficult situation are lack of funding and management problems. Regarding the prospects of resolving this block of issues, they can be solved by medical self-government bodies with appropriate legal support due to the adoption of the Law on Self-Government of Medical Professions in Ukraine.

Key words: protection of the interests of a nurse and a doctor, self-government; health care system; medical care.

Метою дослідження було проаналізувати питання захисту інтересів медсестер та лікарів у системі охорони здоров'я України для можливостей вирішення цих проблем на засадах професійного самоврядування.

\section{МАТЕРІАЛИ I МЕТОДИ}

Використовуючи методи системного аналізу, показано частку питань, що стосуються захисту інтересів медсестер та лікарів у самоврядних прооресійних організаціях в Україні.

\section{РЕЗУЛЬТАТИ Й ОБГОВОРЕННЯ}

У 1987 р. в Іспанії на 39 Всесвітній медичній асамблеї було прийнято Мадридську декларацію відносно профресійної автономії і самоуправління [1]. Мета цієї організації полягала у тому, щоб дати можливість медперсоналу вільно реалізовувати свої профресійні рішення при наданні медичної допомоги своїм пацієнтам. Разом з тим передбачалась і відповідальність за контроль над професійною поведінкою та діяльністю окремих медсестер та лікарів. У світлі цієї декларації майже усі європейські країни створили свої самоврядні медичні організації. Інтереси медсестер та лікарів у тих організаціях відображені по-різному в різних країнах.

В Україні прообразом самоврядних організацій $€$ громадські організації, такі, як Лікарське товари- 
ство, Асоціації медсестер та лікарів тощо. На жаль, питання інтересів медсестер та лікарів у них відображено доволі слабко. Більше уваги вони приділяють можливостям участі у вирішенні державних питань охорони здоров'я, але лише з правом дорадчого голосу.

що ж до самого медперсоналу та його можливостей, то держава не особливо переймається його інтересами. Більшість питань його безпеки носить досить умовне вирішення, в основному теоретично обґрунтованих і дуже слабореалізованих на практиці. Зазвичай ці проблеми має вирішувати заклад охорони здоров'я, у якому працює медичний працівник, або він сам, за власні кошти. Зрозуміло, що при відсутності у цих питаннях жорсткого регламентування та відповідальності-вони вирішуються у дуже різноманітному діапазоні, за принципом можливостей та зацікавленості даного закладу, а більше за максимальною можливістю їх нереалізації. Тому безпека медперсоналу в Україні сьогодні більше нагадує принцип «спасіння потопаючого - справа рук самого потопаючого», аніж гарантія його охорони з боку закладу та держави. Причинами такої незадовільної ситуації є певні труднощі фрінансування, а більше можливості не вирішувати дані питання, відсутність відповідальності - одна 3 них. Отож, вирішення цього блоку питань найраціональніше повинні контролюватися та відстоюватися органами медичного самоврядування.

Аналогічно із безпекою є проблемна ситуація 3 постійним підвищенням кваліфікації персоналу. Це ще одна віха діяльності органів медичного самоврядування. Більшість вебінарів, дистанційних курсів підвищення кваліфрікації, конференцій відбувається на платній основі, що $є$ абсолютно логічним. Питання їх оплати - це питання риторичне. Лікарі, як і медсестри, знаходяться в ситуації, коли з одного боку, на законодавчій основі, з них вимагається постійне підвищення свого кваліфікаційного рівня, а 3 іншого, фрінансове вирішення цього питання майже ніяк не оговорюється в правовому полі. Тому знову ж таки, на жаль, сьогодні працює принцип: «Кожному, хто має, то додасться ще більше і матиме він надміру, а у того, в кого нічого не має, відніметься і той дріб'язок, що йому належить» [2]. Саме органи медичного самоврядування можуть пропонувати та реалізовувати проекти та схеми підвищення кваліфрікації, застосовуючи різноманітні мотиваційні чинники для удосконалення кваліфікації медперсоналу.

Питання оплати праці медичних працівників вже так давно піднімається в засобах масової інфрормації, що уже набило усім оскому, а «віз і нині там». У чому полягає проблема того, що вже сьогодні меншої заробітної плати, ніж у медпрацівників немає ні в кого. щоб відповісти на це запитання необхідно проаналізувати механізм оплати їх праці.

У постреформній сорері охорони здоров'я стався такий парадокс: лікувально-профілактичні заклади відійшли від бюджетної сорери і стали самостійними комунальними некомерційними підприємствами, які тепер працюють на основі Господарського Кодексу України [4]. Необхідно зазначити, що до сьогодні єдиної схеми оплати праці медичних працівників немає. Механізми оплати праці повинні фріксуватися у колективному договорі медичного закладу. Однак тут є багато варіацій і умовностей, що залежать від компетентності та активності медичних працівників та добросовісності керівництва.

Комунальні некомерційні підприємства, які є закладами охорони здоров'я, можуть до певної міри самостійно визначати систему оплати праці в своїх колективах. До сьогодні більшість комунальних некомерційних підприємств при визначенні оплати праці своїх працівників орієнтується на Єдину тарифрікаційну систему бюджетних працівників та Умови оплати праці працівників закладів охорони здоров'я та установ соціального захисту населення, наказ Мінпраці та МО3 від 05.10.2005 р. № 308/519 [5], не дивлячись на те, що запропоновано методичні рекомендації щодо розробки системи оплати праці в закладах охорони здоров'я КНП.

Знову, як бачимо, найвразливіше питання медпрацівників - оплату їх праці вирішують чиновники. Необхідно відмітити, що система оплати праці у закладі охорони здоров'я повинна бути прописана у колективному договорі, який є обов'язковим документом закладу. Але участь медпрацівників у розробці цього надважливого питання зводиться найчастіше просто до голосування на зборах трудового колективу. Розміри виплат в основному залежать від виділених НСЗУ фрінансів.

Посадові ж оклади (тарифрні ставки) працівників бюджетної ссрери за Єдиною тарифною сіткою на 2021 р. та дотримання державних гарантій в оплаті праці визначаються відповідно до постанови Кабінету Міністрів України від 20.01.2021 № 29 «Деякі питання оплати праці працівників установ, закладів та організацій окремих галузей бюджетної сфери» 31 січня 2021 р. посадові оклади (тарифні ставки) працівника 1 тарифного розряду складає 2670 грн, з 1 грудня 2021 р. - 2893 грн [6].

Керівники закладів охорони здоров'я КНП в ідеалі повинні забезпечити диференціацію заробітної плати працівників, які отримують заробітну плату на рівні мінімальної у межах фронду оплати праці, шляхом встановлення доплат, надбавок, премій 3 урахуванням складності, відповідальності та умов виконуваної роботи, кваліфрікації працівника, результатів його роботи. Що і повинно бути прописано в колективному договорі.

Посадові оклади (тарифні ставки) за розрядами Єдиної тарифної сітки визначаються шляхом множення окладу (ставки) працівника 1 тарифнного розряду на відповідний тарифний коефіцієнт.
ISSN 2706-6282(print)

ISSN 2706-6290(online)
Вісник медичних і біологічних досліджень

Bulletin of Medical and Biological Research
$4(10), 2021$ 
Питання оплати праці працівників закладів охорони здоров'я врегульовані Умовами оплати праці працівників закладів охорони здоров'я та установ соціального захисту населення, затвердженими спільним наказом Мінсоцполітики та МО3 від 05.10.2005 р. № 308/519 [7] (табл.).

Для реорганізованих закладів охорони здоров'я - комунальних некомерційних підприємств (КНП) $€$ Методичні рекомендації та роз'яснення з питань укладення колективних договорів комунальних некомерційних підприємств [8], які передбачають такі моделі оплати праці, як «100 \% зарплата», «Заробітна плата плюс бонуси», модель рівних часток та модель продуктивності. У 2020 р. в оплаті медпрацівників з'явилися доплати, пов'язані з боротьбою із пандемією COVID-19 [9].
Як бачимо, теоретичних можливостей для дифреренціації заробітної плати медичних працівників $€$ на сьогодні достатньо, однак вирішальне слово у більшості випадків не за медпрацівниками, тому рішення даного питання мало би стати центральною фрункцією медичного самоврядування [10].

Саме низька зарплата, за матеріалами дослідження проекту «Розробка дорожньої карти розвитку медсестринства в Україні» за підтримки Міжнародного фронду «Відродження», який виконувався аналітичним центром «Вокс Україна» та Центром розвитку медсестринства Міністерства охорони здоров'я України, є причиною того, що медсестри та медбрати йдуть із професії чи виїжджають до інших країн. У розвинених країнах медсестри та медбрати отримують все більше повноважень,

Таблиця. Схеми тарифних розрядів посад медсестер та лікарів

\begin{tabular}{|c|c|}
\hline & $\begin{array}{c}\text { Тарисрний } \\
\text { розряд }\end{array}$ \\
\hline \multicolumn{2}{|l|}{$\begin{array}{l}\text { Лікарі-хірурги усіх найменувань і лікарі-ендоскопісти, лікарі-анестезіологи, лікарі загальної прак- } \\
\text { тики - сімейної медицини: }\end{array}$} \\
\hline - вищої кваліфікаційної категорії; & 14 \\
\hline - першої кваліфрікаційної категорії; & 13 \\
\hline - другої квалісрікаційної категорії; & 12 \\
\hline - без категорії & 11 \\
\hline $\begin{array}{l}\text { Лікарі-інтерни, лікарі-стажисти за такими лікарськими спеціальностями: } \\
\text { лікар-хірург (усіх найменувань), лікар-ендоскопіст, лікар-анестезіолог, лікар загальної практики - } \\
\text { сімейної медицини }\end{array}$ & 10 \\
\hline \multicolumn{2}{|l|}{ Лікарі інших спеціальностей: } \\
\hline - вищої кваліфрікаційної категорії; & 13 \\
\hline - першої кваліфрікаційної категорії; & 12 \\
\hline - другої кваліфрікаційної категорії; & 11 \\
\hline - без категорії & 10 \\
\hline Лікар-інтерн, лікар-стажист за іншими лікарськими спеціальностями & 9 \\
\hline $\begin{array}{l}\text { Трансплант-координатор, трансплант-координатор патологоанатомічного бюро (бюро судово- } \\
\text { медичної експертизи) }\end{array}$ & 13 \\
\hline \multicolumn{2}{|l|}{$\begin{array}{l}\text { Акушерки, сестри медичні: операційних, перев'язувальних, відділень (груп, палат) анестезіології } \\
\text { та інтенсивної терапії, пологових будинків (відділень, палат), відділень (палат) новонароджених } \\
\text { та недоношених дітей, станцій (відділень) швидкої, невідкладної, екстреної медичної допомо- } \\
\text { ги, кабінету з аудіометрії; оптометристи; помічники: лікаря-епідеміолога, лікаря-стоматолога; } \\
\text { фельдшери всіх спеціальностей, лаборанти (фельдшери-лаборанти), медичні сестри загальної } \\
\text { практики - сімейної медицини*, стоматологи: }\end{array}$} \\
\hline - вищої квалісрікаційної категорії; & 10 \\
\hline - першої кваліфікаційної категорії; & 9 \\
\hline - другої кваліфрікаційної категорії; & 8 \\
\hline - без категорії & 7 \\
\hline \multicolumn{2}{|l|}{$\begin{array}{l}\text { Інструктори, рентгенолаборанти, медсестри: поліклінік і стаціонарів, з дієтичного харчування, } \\
\text { з лікувальної фрізкультури, з масажу, зі стоматології, з фрізіотерапії та інші; статистики медичні, } \\
\text { техніки зубні, техніки-ортезисти- гіпсовиливальники: }\end{array}$} \\
\hline - вищої кваліфрікаційної категорії; & 9 \\
\hline - квалісрікаційної категорії; & 8 \\
\hline - другої кваліфрікаційної категорії; & 7 \\
\hline - без категорії & 6 \\
\hline
\end{tabular}

Примітка. * медичним сестрам, призначеним на посади сестер загальної практики - сімейної медицини, зберігається протягом 3 років кваліфікаційна категорія за спеціальностями «Фельдшер», «Фельдшер швидкої допомоги», «Акушерка жіночої консультації», «Медична сестра стаціонару», «Медична сестра поліклініки», Медична сестра дитячого стаціонару», «Медична сестра дитячої поліклініки». 
що сприяє ефрективному використанню людського потенціалу та фрінансових ресурсів у медицині [11]. Цьому питанню приділяється значна увага на багатьох рівнях, що відображено в численних наукових публікаціях іноземних видань [11-17], 3окрема вирішенню питань, пов'язаних із професійним вигорянням медсестер [11, 12], їх якості життя [13], адекватності навантаження [14], проблеми нестачі медсестер та текучості кадрів у лікувальних закладах $[14,15]$, ризиків інфрікування під час виконання професійних обов'язків [11], задоволеність роботою та проблеми взаємодії з іншим персоналом лікарень та інших лікувальних закладів $[12,16]$, особливості праці середнього медперсоналу в період пандемії COVID-19 [17]. Водночас українська медична реформа залишила середній медичний персонал поза орокусом уваги [18].

Питання оплати праці медичних працівників тісно пов'язане із вартістю медичних послуг, а відповідно і доступністю до неї населення. Пункт 6 Мадридської декларації наголошує на істотності даних питань для самоврядування і тому Національні медичні асоціації повинні включати діяльність щодо обмеження вартості в свої відповідні системи самоврядування [1]. У цьому ж пункті говориться, що: «Не можна дозволяти, щоб невиправдане використання медичної техніки призводило до збільшення вартості медичної допомоги до такого рівня, що вона стане недоступною для потребуючих звичайної медичної допомоги» [1].

\section{СПИСОК ЛІТЕРАТУРИ}

1. Мадридська декларація відносно професіональної автономії медсестер та лікарів і самоуправління, прийнята 39-ю Всесвітньою медичною асамблеєю. - Мадрид, Іспанія, 1987 [Електронний ресурс]. - Режим доступу: https://med.sumdu.edu.ua/images/content/doctors/ Deontology/Madrid_1987.pdf

2. Від Матвія 25:29 UMT - Свята Біблія - Bible. com [Електронний ресурс]. - Режим доступу: https://www. bible.com > UMT].

3. Про рішення Ради національної безпеки і оборони України від 30 липня 2021 року «Про стан національної системи охорони здоров'я та невідкладні заходи щодо забезпечення громадян України медичною допомогою» : Указ Президента України № 369/2021 [Електронний ресурс]. - Режим доступу: https://www.president.gov.ua/ documents/3692021-39713

4. Відомості Верховної Ради України (ВВР), 2003, № 18, № 19-20, № 21-22, ст.144 : Господарський Кодекс України [Електронний ресурс]. - Режим доступу: https:// zakon.rada.gov.ua/laws/show/436-15\#Text

5. Про впорядкування умов оплати праці працівників закладів охорони здоров'я та установ соціального захисту населення : Наказ Міністерства праці та соціальної політики України від 05.10.2005 № 308/519 [Електронний
Пункт 9. Мадридської декларації відмічає, що Всесвітня медична асоціація та Національні медичні асоціації повинні також інформувати громадськість про існування еорективної і надійної системи самоврядування в медицині кожної країни. «Суспільство має усвідомити, що воно може покластися на цю систему самоврядування в питаннях чесної і об'єктивної оцінки проблем, пов'язаних з медичною практикою, наданням допомоги і лікуванням пацієнтів», - говориться в декларації [1].

\section{ВИСНОВКИ}

1. Результати аналізу ситуації захисту медичних працівників та їх безпеки в системі охорони здоров'я України дозволив виявити певні проблеми, що здебільшого полягають у недостатніх правових та орінансових гарантій для медичних працівників, а також організаційних прогалин, зокрема відсутності чіткої стратегії профресійного медсестринського та медичного самоврядування.

2. Безпека медпрацівників в Україні сьогодні більше нагадує принцип «порятунок потопаючого - справа рук самого потопаючого», аніж гарантія захисту з боку медичного закладу та держави.

3. Причинами такої складної ситуації $€$ не фрінансування та управлінські проблеми. Щодо перспектив вирішення цього блоку питань, то найраціональніше вказані проблеми можуть бути вирішені органами медичного самоврядування при належному юридичному забезпеченні, чому сприятиме прийняття Закону про самоврядування медичних професій в Україні.

ресурс]. - Режим доступу: https://zakon.rada.gov.ua/laws/ show/z1209-05\#Text.

6. Деякі питання оплати праці працівників установ, закладів та організацій окремих галузей бюджетної ссрери : Постанова Кабінету Міністрів України від 20.01.2021 № 29 [Електронний ресурс]. - Режим доступу: https:// zakon.rada.gov.ua/laws/show/29-2021-\%D0\%BF\#Text

7. Про впорядкування умов оплати праці працівників закладів охорони здоров'я та установ соціального захисту населення : Наказ Мінсоцполітики 05.10.2005 № 308/519 [Електронний ресурс]. - Режим доступу: http:// ck.dsp.gov.ua/?q=article/nakaz-minsocpolityky-05102005no308519-pro-vporyadkuvannya-umov-oplaty-pracipracivnykiv.

8. Методичні рекомендації та роз'яснення з питань укладення колективних договорів комунальних некомерційних підприємств [Електронний ресурс]. - Режим доступу: https://moz.gov.ua/uploads/3/19289-b_coll_ dogovor_ua_v105_03_03_2020.pdf

9. Оплата праці медичних працівників КНП 2021 [Електронний ресурс]. - Режим доступу: https://www. golovbukh.ua/article/7578-oplata-prats-derjavn-garant.

10. Проект Закону про самоврядування медичних професій в Україні № 2445-д від 03.07.2020 [Електро-
ISSN 2706-6282(print)

ISSN 2706-6290(online)
Вісник медичних і біологічних досліджень

Bulletin of Medical and Biological Research
$4(10), 2021$ 
нний ресурс]. - Режим доступу: http://w1.c1.rada.gov.ua/ pls/zweb2/webproc4_1?pf3511=69359

11. Nurse staffing, burnout, and health care-associated infection / J. P. Cimiotti, L. H. Aiken, D. M. Sloane, E. S. Wu // Am. J. Infect. Control. - 2012. - Vol. 40 (6). - P. 486-490. DOI: 10.1016/j.ajic.2012.02.029.

12. Stress and burnout syndrome and their associations with coping and job satisfaction in critical care nurses: a literature review / A. Friganović, P. Selič, B. Ilić, B. Sedić // Psychiatr. Danub. - 2019. - Vol. 31 (Suppl. 1). - P. 221-231.

13. The quality of work life of registered nurses in Canada and the United States: a comprehensive literature review / B. Nowrouzi, E. Giddens, B. Gohar [et al.] // Int. J. Occup. Environ. Health. - 2016. - Vol. 22 (4). - P. 341-358. DOI: $10.1080 / 10773525.2016 .1241920$.

14. Toh S. G. Systematic review on the relationship between the nursing shortage and job satisfaction, stress and burnout levels among nurses in oncology/haematology

\section{REFERENCES}

1. Madrid Declaration on the Professional Autonomy of Nurses and Physicians and Self-Government Adopted by the 39th World Medical Assembly, Madrid, Spain. 1987 Available from: https://med.sumdu.edu.ua/images/content/ doctors/Deontology/Madrid_1987.pdf Ukrainian.

2. Matthew 25:29 UMT - Holy Bible Available from: https://www.bible.com > UMT. Ukrainian.

3. Decree of the President of Ukraine No. 369/2021 On the decision of the National Security and Defense Council of Ukraine of July 30, 2021 "On the state of the national health care system and urgent measures to provide citizens of Ukraine with medical care" Available from: https://www. president.gov.ua/documents/3692021-39713. Ukrainian.

4. Economic Code of Ukraine. Information of the Verkhovna Rada of Ukraine (VVR). 2003;18,19-20,2122:144 Available from: https://zakon.rada.gov.ua/laws/ show/436-15\#Tex. Ukrainian.

5. Order of the Ministry of Labor and Social Policy of Ukraine dated October 5, 2005 No. 308/519 On streamlining the conditions of remuneration of employees of health care institutions and social protection institutions Available from: https://zakon.rada.gov.ua/laws/show/z1209-05\#Text. Ukrainian.

6. Resolution of the Cabinet of Ministers of Ukraine of January 20, 2021 No. 29 "Some issues of remuneration of employees of institutions, establishments and organizations of certain sectors of the budget sphere" Available from: https:// zakon.rada.gov.ua/laws/show/29-2021-\%D0\%BF\#Text. Ukrainian.

7. Order of the Ministry of Social Policy October 5, 2005 No. 308/519 On streamlining the conditions of remuneration of employees of health care institutions and social protection institutions Available from: http://ck.dsp.gov.ua/?q=article/ nakaz-minsocpolityky-05102005-no308519-provporyadkuvannya-umov-oplaty-praci-pracivnykiv. Ukrainian.

8. Methodical recommendations and explanations on the issues of concluding collective agreements of communal non-profit enterprises Available from: https://moz.gov.ual uploads/3/19289-b_coll_dogovor_ua v105 0303 2020.pdf. Ukrainian. settings / S. G. Toh, E. Ang, M. K. Devi // Int. J. Evid. Based Healthc. - 2012. - Vol. 10 (2). - P. 126-141. DOI: 10.1111/j.1744-1609.2012.00271.x.

15. Kelly L. A. Impact of nurse burnout on organizational and position turnover / L. A. Kelly, P. M. Gee, R. J. Butler // Nurs Outlook. - 2021. - Vol. 69 (1). - P. 96-102. DOI: 10.1016/j.outlook.2020.06.008. Epub 2020 Oct 4.

16. Edmonson C. Our own worst enemies: The nurse bullying epidemic / C. Edmonson, C. Zelonka // Nurs Adm. Q. - 2019. - Vol. 43 (3). - P. 274-279. DOI: 10.1097/ NAQ.0000000000000353.

17. Treston C. J. COVID-19 in the year of the nurse / C. J. Treston // Assoc. Nurses AIDS Care. - 2020. - Vol. 31 (3). - P. 359-360. DOI: 10.1097/JNC.0000000000000173.

18. Непомітне медсестринство: як змінити ситуацію? Дорожня карта розвитку медсестринства в Україні 2021-2023 [Електронний ресурс]. - Режим доступу: medsestrynstvo-web.pdf (voxukraine.org).

9. Remuneration of medical workers of KNP 2021 Available from: https://www.golovbukh.ua/article/7578oplata-prats-derjavn-garant. Ukrainian.

10. Draft Law on Self-Government of Medical Professions in Ukraine № 2445-d. 03.07.2020 Available from: http:// w1.c1.rada.gov.ua/pls/zweb2/webproc4_1?pf3511=69359. Ukrainian.

11. Cimiotti JP, Aiken LH, Sloane DM, Wu ES. Nurse staffing, burnout, and health care-associated infection. Am J Infect Control. 2012;40(6): 486-90. DOI: 10.1016/j. ajic.2012.02.029.

12. Friganović A, Selič $P$, Ilić $B$, Sedić B. Stress and burnout syndrome and their associations with coping and job satisfaction in critical care nurses: a literature review. Psychiatr. Danub. 2019;31(Suppl. 1): 21-31.

13. Nowrouzi B, Giddens E, Gohar B, Schoenenberger S, Bautista MC, Casole J. The quality of work life of registered nurses in Canada and the United States: a comprehensive literature review. Int J Occup Environ Health. 2016;22(4): 341-58. DOI: 10.1080/10773525.2016.1241920.

14. Toh SG, Ang E, Devi MK. Systematic review on the relationship between the nursing shortage and job satisfaction, stress and burnout levels among nurses in oncology/haematology settings. Int J Evid Based Healthc. 2012;10(2): 126-41. DOI: 10.1111/j.17441609.2012.00271.x.

15. Kelly LA, Gee PM, Butler RJ. Impact of nurse burnout on organizational and position turnover. Nurs Outlook. 2021;69(1): 96-102. DOI: 10.1016/j.outlook.2020.06.008. Epub 2020 Oct 4.

16. Edmonson C, Zelonka C. Our own worst enemies: The nurse bullying epidemic. Nurs Adm Q. 2019;43(3): 2749. DOI: 10.1097/NAQ.0000000000000353.

17. Treston CJю COVID-19 in the Year of the Nurse. Assoc Nurses AIDS Care. 2020; 31(3): 359-60. DOI: $10.1097 /$ JNC.0000000000000173

18. Inconspicuous nursing: how to change the situation? Roadmap for the development of nursing in Ukraine 2021-2023. Available from: medsestrynstvo-web.pdf (voxukraine.org) 